\title{
Thiazide diuretics-associated skin rash
}

\author{
Filipe Santos Mira, ${ }^{1}$ Helena Temido, ${ }^{2}$ Elsa Gaspar ${ }^{2}$
}

${ }^{1}$ Nephrology, Centro Hospitalar e Universitario de Coimbra EPE, Coimbra, Portugal Internal Medicine, Centro Hospitalar e Universitário de Coimbra, Coimbra, Portugal

\section{Correspondence to} Dr Filipe Santos Mira, filipemira@netcabo.pt

Accepted 23 May 2018

\section{DESCRIPTION}

A 50-year-old man with a history of hypertension and dyslipidaemia, both controlled with oral medications, was admitted to the emergency department due to a sudden onset of pruritus 2 days before, which would not improve with the application of topic antihistamines prescribed by his family doctor. A maculopapular, symmetric rash with plaques located on sun-exposed areas (hands, forearms, face and upper torso, sparing the abdomen, lower limbs and arm flexures) had appeared a few hours before coming to the emergency department (figures 1 and 2). The patient denied any sort of respiratory distress, as well as prolonged exposure to sunlight, history of drug allergies or having seen anyone in his family with the same problem before. The only recent change had been to his hypertension medication in the last 13 days, when hydrochlorothiazide was combined with his usual medication (losartan), which he had been taking for the past 5 years. Since photosensitivity due to thiazides was a possibility, he was given a single-dose intravenous steroid (40 mg of methylprednisolone), which improved his symptoms and so he was advised to stop hydrochlorothiazide until the next consultation. Five days later he came for consultation and did not present any of the mentioned skin lesions, thus confirming the diagnosis.

The prevalence of thiazide-related photosensitivity is estimated between 1 and 100 per 100000 patients, ${ }^{1}$ with hydrochlorothiazide being the most common agent. There are only a few cases described in the literature. ${ }^{12}$ Due to its low prevalence, one must recognise it in the clinical context in order to act accordingly and to be able to discharge the patient with the right medication.

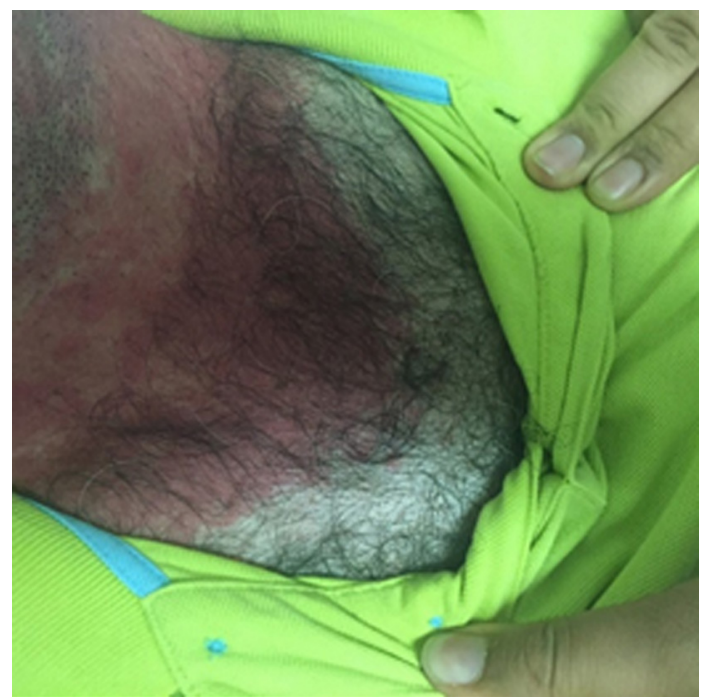

Figure 1 Skin rash limited to the neck.

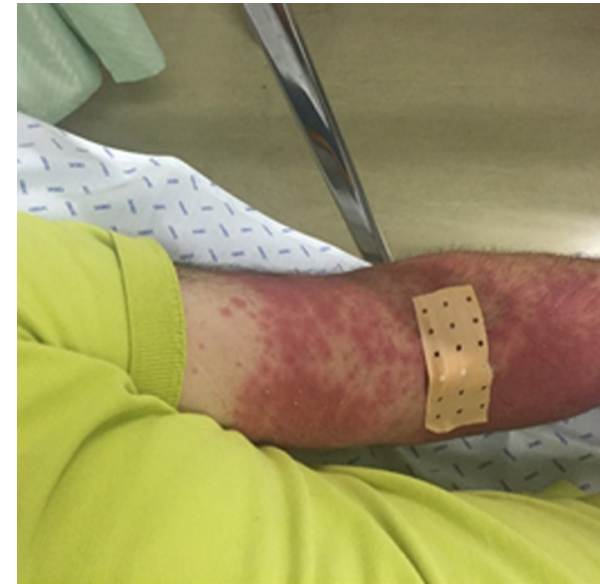

Figure 2 Skin rash on the arm limited to the sunexposed region.

\section{Learning points}

A photosensitive skin rash can be present in a multitude of diseases, ranging from autoimmune (namely subacute cutaneous lupus erythematosus) to allergic and even drug-associated diseases; therefore, a thorough clinical examination and questioning must be prioritised.

- Every clinician must be aware of the possible causes of a photosensitive rash since it can be associated with systemic diseases, which require a swift and accurate diagnosis in order to provide adequate treatment

- Unless it is clinically obvious, as in the case of a recent drug exposure, before any therapeutic measure is taken, further investigation through skin biopsies and laboratory tests (such as antinuclear antibody panels and porphyrin) may be required to confirm the diagnosis.

- Thiazides can elicit a photoallergic or a phototoxic response; in this case, a photoallergic dermatitis is present with a delayed onset and mild symptomatology, even though it is not usually associated with systemically administered substances.

Contributors FSM drafted the article and followed the patient's case closely in the emergency department and took the pictures. HT followed the patient's case and helped to draft and create the article. EG followed the patient's case as well and corrected the article.

Funding The authors have not declared a specific grant for this research from any funding agency in the public, commercial or not-for-profit sectors.

Competing interests None declared.

Patient consent Obtained. 


\section{Images in...}

Provenance and peer review Not commissioned; externally peer reviewed.

(C) BMJ Publishing Group Ltd (unless otherwise stated in the text of the article) 2018. All rights reserved. No commercial use is permitted unless otherwise expressly granted.

\section{REFERENCES}

1 Gómez-Bernal S, Alvarez-Pérez A, Rodríguez-Pazos L, et al. Photosensitivity due to thiazides. Actas Dermosifiliogr 2014;105:359-66.

2 Monroe JR. A common cause of photodistributed rash. J Am Acad Physician Assist 2006;19:53.

Copyright 2018 BMJ Publishing Group. All rights reserved. For permission to reuse any of this content visit http://group.bmj.com/group/rights-licensing/permissions.

BMJ Case Report Fellows may re-use this article for personal use and teaching without any further permission.

Become a Fellow of BMJ Case Reports today and you can:

- Submit as many cases as you like

- Enjoy fast sympathetic peer review and rapid publication of accepted articles

- Access all the published articles

- Re-use any of the published material for personal use and teaching without further permission

For information on Institutional Fellowships contact consortiasales@bmjgroup.com

Visit casereports.bmj.com for more articles like this and to become a Fellow 